\title{
MARKETING CHANNEL OF PINEAPPLE IN ISABELA, PHILIPPINES
}

\author{
DOI: 10.17261/Pressacademia.2019.1035 \\ JMML- V.6-ISS.2-2019(2)-p.73-83
}

\section{Dolores B. Galvez}

Nueva Vizcaya State University, College of Business Education, Business Administration Department, Philippines. galvezdolores@rocketmail.com, ORCID 0000-0002-1872-5486

Galvez, D. B. (2019). Marketing channel of pineapple in Isabela, Philippines. Journal of Management, Marketing and Logistics (JMML), V.6(2), p.73-83, DOI: 10.17261/Pressacademia.2019.1035

Permemant link to this document: http://doi.org/10.17261/Pressacademia.2019.1035

Copyright: Published by PressAcademia and limited licenced re-use rights only.

\section{ABSTRACT}

Purpose - The study determined the key production area, farming practices, average production volume, marketing channels, and marketing practices of pineapple farmers in Isabela, Philippines.

Methodology- Primary and secondary data were used. Through multistage sampling, eighty -four pineapple farmers were chosen to be the respondents as they answered closed and open- ended questions.

Findings- Municipalities with pineapple farms are Echague, San Guillermo, Sto. Tomas, Jones, and Angadanan. Pineapple farmers fertilized their farm and covered the fruit with hay to protect it from the sun. Their average production volume was about 23,588 pieces per cropping. The four intermediaries in the channel were canvassers, traders, processors, and retailers. Their marketing practices involved their reasons for choosing the type of buyers, basis in determining the quality of fruit, reasons for product rejection, price monitoring, and negotiation. Conclusion- Most farmers did not have the capacity of marketing their produce. They just waited for their buyers to come in their area.

Keywords: Farmers, Farm activities, Marketing channel, Marketing practices, Pineapple JEL Codes: M19, M30, M39

\section{INTRODUCTION}

Philip Kotler defined marketing as the science and art of exploring, creating, and delivering value different from competitor to satisfy the needs of the target market at a profit. Marketing is everywhere: in the academe, hospital, agriculture, bank, food, any type of industry you name it, marketing is important. Marketing is composed of $4 \mathrm{P}^{\prime} \mathrm{s}$, the marketing mix, namely product, price, promotion, and place. Products refer to the goods or services. Price refers to the amount purchased by the seller in exchange of the goods or service. Promotion is creating a strategy so that customers would be aware of the product. Lastly, place is the distribution of goods or services. Promotion and place, (distribution or marketing channels) are the focused of this study. The product is useless if the people are not aware of it. Even though people would be aware of the products, but if they would not be available in their area, it would be useless. Thus, promotion and place (distribution or marketing channels) are also important in every industry. There is a great demand on food. Food is the basic necessity of every person, moreover, food business is also the source of income of many Filipinos. If there was demand, there should be enough supply, but how would one satisfy the demand? How would one bring the product to the consumers? In order to reach the goods to the ultimate consumers, marketing channel should be included in the scenario. According to Blunt (2019), the types of marketing channels are manufacturer direct to customer, manufacturer to retailer to customer, manufacturer to wholesaler to customer, and manufacturer to agent to wholesaler to retailer to customer. However, in the case of agricultural industry specifically in farming, the manufacturers are the farmers. Farmers who plant fruits or vegetables then used different marketing channels for them to sell their produce. 
The more intermediaries in the distribution system, the higher the selling price, thus, consumers are the most affected in the marketing chain. Agarwal (nd) mentioned four levels in distribution. In zero level channel, there is no intermediary involved. The producer directly sells products to consumers. One level channel involves one intermediary who is the retailer. Thus, the manufacturer sells products to retailers. Two level channel obviously involves two intermediaries who are wholesaler and retailer. In this event, the wholesaler purchases the products from the manufacturer and sells them to retailers. In three level channel, the other intermediary is the jobber. To complete the chain, the manufacturer sells products to wholesaler, then the jobber will purchase the products from the wholesaler and sells them to the retailer. Retailers are the last intermediary before the consumer, thus, they are the most powerful in the chain.

Marketing channel's choice is based on farmers' decision. The four factors affecting their choice are price, quantity and quality of product, distance between farm and selling, and service rendered by buyers (Apandi, et al, 2017). The Philippines is a tropical country and rich in agricultural lands, thus, one of the livelihood of Filipinos is farming. Based on the data of PSA 20102014 the major crops in the country are palay, corn, coconut, sugarcane, banana, pineapple, coffee, mango, tobacco, abaca, peanut, mongo, cassava, sweet potato, tomato, garlic, onion, cabbage, eggplant, calamansi and rubber. However, palay and corn represent 60 percent of the total crop production. When it comes to fruit export, banana, pineapple, mango, papaya, and calamondin are the champions (Rodeo, 2016). Pineapple is a tropical fruit which belongs to bromeliad family and one of the few bromeliads to produce edible fruit (Szalay, 2018). The fruit's scientific name is Ananas Comosus and it is divided into four categories: Smooth Cayenne, Queen, Abacaxi, and Red Spanish. Rodeo (2016) mentioned that Smooth Cayenne and Queen or Formosa are the two major cultivars of pineapple for fresh consumption and processing in the country. Based on the study of Joy (2010) the fruit contains calcium, potassium, fiber, and vitamin C. Moreover, it is considered a digestive aid and a natural anti-inflammatory fruit. Pineapple is also used for tenderizing meat since it is rich in bromelain. The fruit is also rich in fiber that is why people suffering from constipation and irregular bowel movement may eat pineapple.

Costa Rica is the leading producer of pineapple in the world with annual production of 26853.12 thousand metric tons per year. Its tropical climate is suitable for the heavy growth of the fruit. Next to Costa Rica is Brazil with 2500 thousand metric tons in production. Third in the list is Philippines with a production of approximately 2400 thousand metric tons in the past year. Philippines is also the $3^{\text {rd }}$ largest pineapple exporter (Khan, 2018). Santiago (2017) reported that South Korea, Japan, China, United Arab Emirates, Iran, Saudi Arabia, Taiwan, Hong Kong, New Zealand, and United States bought $97.7 \%$ of all Filipino pineapple exports in 2016. Based on the record of Philippine Statistics Authority (PSA) April to June 2018, the highest pineapple producer in the Philippines was Northern Mindanao (50.6\%) followed by SOCCSKSARGEN (25.8\%), other regions (13.9\%) and Calabarzon (9.7\%). On October to December 2018, pineapple production had an increment of 1.0\%, reaching 706.46 thousand metric tons. Almost two-thirds of pineapple production in the country was from Northern Mindanao (PSA, October-December 2018).

Cagayan Valley represents small portion in Philippine Pineapple Industry with only 720 MT produced in 2015 (PSA, 2016$).$ The region ranked $8^{\text {th }}$ among the 17 pineapple producers in the country. In Region 02, Nueva Vizcaya, Isabela, and Cagayan are the top 3 producers of pineapple. Based on the record of the Office of Provincial Agriculturist-Isabela (2016) Echague, Jones, San Guillermo, Angadanan, and Sto. Tomas are the municipalities with most number of pineapple farmers. This study determined the (1) key production area, (2) farming practices, (3) average production volume, (4) different marketing channels, and (5) marketing practices of pineapple farmers in Isabela, Philippines.

Key production area refers to the specific area where pineapples are planted. What are pineapple farmers farming practices that is unique from other pineapple farmers? In marketing, good quality product is important, thus, pineapple farmers' farming practices entail an effect to the quality of their produce. Demand should be satisfied, hence, this study determined the average production volume per farmer. As discussed earlier, marketing is everywhere. This research would determine the marketing channels and marketing practices used by pineapple farmers. This study would help pineapple farmers to improve their decision in choosing marketing channels. Further, those farmers who do not have marketing skills may now have an idea on how to improve and market their products.

\section{LITERATURE REVIEW}

Yusi (2016) mentioned that pineapple contributes eight percent of the world fresh fruit production. Further, it is a proven commodity which has market opportunities domestically and abroad. Pineapple farming generate employment for rural people (Das et al, 2016). Most pineapple farmers belong to marginal sector, hence, they cannot undertake value addition operations (Arcelo, nd). Likewise, agricultural development's purpose in Indonesia is to reduce poverty of villagers, meet the food needs of 
the society, the needs of raw materials in the country, prevent migration, increase foreign exchange through export, expand employment opportunities, increase the income of the society, and support the distribution development results (Yusi, 2016).

\subsection{Culture and Management}

Arcelo (nd) stated in her study, pineapple requires mild and relative temperature about 24 to 30 degree Celsius, evenly distributed rainfall (100-150 cm / year), and a very short dry season. Suckers, slips, and crowns are used as planting materials for propagation. These should be exposed to sunlight for one week or more depending on the weather conditions. Suckers which will bear in 16 to 18 months form at the base and axil of the leaves. Slips develop at the base or above the ground which bears $18-20$ months. Crowns form on top of the fruit which will bear in $22-24$ months. Before planting, land and soil must be prepared thoroughly. For commercial farms, crowns are commonly used while slips and suckers are planted in small farms. In small scale planting, farmers intercropped pineapples with coconut, papaya, coffee, or banana. Weeds compete with pineapple for nutrients and sunlight, thus, weed management is one of the major constraints in harvesting high yield. Harvesting the fruit depends upon the maturity. In small farms, pineapples are harvested manually. They are placed on a well shaded and clean area to minimize weight loss and microbial contamination. In transporting the fruits, they should be arranged lying on their sides in an alternate crown-to-base fashion to reduce physical damage.

\subsection{Marketing Channels}

Based on the study of Das et al (2016) there are six marketing channels in West Bengal, India. The channels are: Channel IProducer $\rightarrow$ Wholesaler $\rightarrow$ Outside Markets $\rightarrow$ *Consumer; Channel II- Producer $\rightarrow$ Trader agent $\rightarrow$ Wholesaler $\rightarrow$ Outside market $\rightarrow^{*}$ Consumer; Channel III - Producer $\rightarrow$ Wholesaler $\rightarrow$ Retailer $\rightarrow$ Consumer; Channel IV- Producer $\rightarrow$ Trader agent $\rightarrow$ Wholesaler $\rightarrow$ Retailer $\rightarrow$ Consumer; Channel V- Producer $\rightarrow$ Wholesaler $\rightarrow$ Factory $\rightarrow$ Outside Market $\rightarrow{ }^{*}$ Consumer; and Channel VI - Producer $\rightarrow$ Wholesaler $\rightarrow$ Middle agent $\rightarrow$ Outside market $\rightarrow$ Consumer. Those with asterisk $\left({ }^{*}\right)$ are incomplete channel, meaning, channels are extended to the markets outside states. Channel 1 depicts the shortest while channel II is the most prominent among the channels. Pineapples are passed on from one intermediary to another. The fruits are graded through visual inspection according to size and vigor. Pineapples are graded into three categories namely: Grade I- fruit with less than one kilogram; Grade II- fruit with $1 \mathrm{~kg}-1.5 \mathrm{~kg}$; and Grade III- fruit with more than $1.5 \mathrm{~kg}$. The retail shop owners sell the produce as raw fruit and juice of raw pineapple. As agricultural product, pineapple needs more attention either in terms of its quantity or marketing system (Yusi, 2016). Marketing system is important for the product to last long. With a good support from marketing system, pineapple farmers are motivated to increase their production. Hence, efficient marketing has effect on the farmer's passion to be more active in production.

\subsection{Marketing Practices}

In West Bengal, small and marginal farmers sell their produce through trade agents (wholesalers) at the village level. This constitutes the $90 \%$ share of pineapple marketing. Moreover, farmers also brought their produce to various marketing functionaries through own arrangements. Due to its high perishability, marketing of fresh pineapple entails serious problems. Almost forty-eight percent (48\%) spoilage is experienced while in transit from Agartala to Kolkata. Further, pricing system of pineapple is not yet developed (Das et al 2016). Nevertheless, farmers cannot determine their products' price freely due to lack of capital and have less information about the market. When they are challenged with urgent needs, they tend to avail loan from middlemen either in cash or in kind. At the end, among the intermediaries along the channel, farmers get the smallest part of the price paid by the consumers (Yusi, 2016). Das et al (2016) enumerated five major constraints in marketing system; (1) weak forward and backward linkages, (2)supply of quality pineapple is for a short period due to poor storage and cool-chain facilities, (3) infrastructure for grading and standardization not available, (4) pricing mechanism is not scientific since it is based on visual inspection only, and (5) lack of cooperative approach for improving bargaining power. Based on the study of Keerthi (2008) marketing is part and parcel of production. Pineapple farmers neither have the time nor the skills to undertake marketing activities. Local fresh fruit markets and processors prefer bigger fruits and medium size fruits (1.3-1.5kg) respectively (Arcelo, nd). Pineapples must be prepared for marketing in a packinghouse protected by sunlight and rain. A quality control system is suggested to meet the customer's requirements, hence, final sorting and grading should be done in the packinghouse. The basis of pricing for local market is based on size or kilogram.

\section{DATA AND METHODOLOGY}

This study used primary and secondary data. Primary data was used in determining the farm activities, average production volume, marketing channels, and marketing practices. Moreover, secondary data was used to determine the key production 
area of pineapple in the province. The data came from the Office of the Provincial Agriculturist (OPAG), Isabela. The primary respondents of the study were the pineapple farmers. Multistage sampling using slovins formula with $10 \%$ margin of error was used in determining the samples. The researcher identified the top three highest municipalities then top three barangays per municipality with the greatest number of farmers.

Table 1: Number of Pineapple Farmers in Isabela

\begin{tabular}{|l|c|}
\hline \multicolumn{1}{|c|}{ Municipality } & No. of Farmer \\
\hline Echague & 266 \\
\hline Jones & 35 \\
\hline San Guillermo & 162 \\
\hline Angadanan & 5 \\
\hline Sto. Tomas & 118 \\
\hline Total & 586 \\
\hline
\end{tabular}

Source: OPAG Isabela, Status of Pineapple Production in the Province of Isabela CY 2016

Table 2: Sample Size of Pineapple Farmers per Barangay

\begin{tabular}{|l|l|r|r|}
\hline Municipality & \multicolumn{1}{|c|}{ Barangay } & Population & \multicolumn{1}{c|}{ Sample } \\
\hline \multirow{3}{*}{ San Guillermo } & Dingading & 90 & 15 \\
\cline { 2 - 4 } & Centro 2 & 83 & 14 \\
\cline { 2 - 4 } & Estrella & 68 & 12 \\
\hline \multirow{3}{*}{ Echague } & Magleticia & 96 & 16 \\
\cline { 2 - 4 } & Mabbayad & 36 & 6 \\
\cline { 2 - 4 } & Villa Rey & 33 & 5 \\
\hline \multirow{3}{*}{ Santo Tomas } & San Rafael Alto & 49 & 8 \\
\cline { 2 - 4 } & San Vicente & 41 & 7 \\
\cline { 2 - 4 } & Ammugauan & 8 & 1 \\
\hline Total & \multicolumn{2}{|c|}{504} & 84 \\
\hline \multirow{2}{*}{ Source: OPAG Isabela, Status of Pineapple Production in the Province of Isabela CY 2016 }
\end{tabular}

Based on table 1, the top three municipalities were Echague, San Guillermo, and Sto. Tomas. Table 2 depicts the sample size per barangay. For Echague, its top three barangays were Brgy. Magleticia, Brgy. Mabbayad, and Brgy. Villarey; for San Guillermo, its top three barangays were Brgy. Dingading, Brgy. Centro Dos, Brgy. Estrella; and for Santo Tomas, there were only two barangays identified namely Brgy. San Rafael Abajo, and San Vicente. Quantitative method was used in objective three where mean, standard deviation, frequency and percentages were identified. Moreover, for objectives two, four and five, open ended questions were used. The questionnaire was validated by the expert before the conduct of the survey.

\section{FINDINGS AND DISCUSSIONS}

\section{Key Production Area of Pineapple}

Among 34 municipalities in Isabela, there were only five municipalities which produced pineapple namely; Echague, Jones, San Guillermo, Angadanan, and Sto. Tomas (See Appendix 1). Isabela had a total land area of 425.66 hectares for pineapple production which was located in 5 municipalities (Table 1). Echague had the largest area which was 287.75 hectares followed by San Guillermo which was 86.87 hectares. The third largest area of production which was 27.89 hectares was found in Sto. Tomas, however, during the conduct of the study, it was found out that most producers were backyard farmers. Furthermore, Jones, and Angadanan had 18.65 hectares and 4.50 hectares respectively.

Table 3: Area Planted Per Municipality

\begin{tabular}{|l|c|}
\hline Municipality & Area Planted(Has) \\
\hline Echague & 287.75 \\
\hline Jones & 18.65 \\
\hline San Guillermo & 86.87 \\
\hline Angadanan & 4.50 \\
\hline Sto. Tomas & 27.89 \\
\hline Total & 425.66 \\
\hline
\end{tabular}

Source: OPAG Isabela, Status of Pineapple Production in the Province of Isabela CY 2016 


\section{Farm Activities}

Pineapple farmers planted, grew, and harvested their produce for an average of twenty-four (24) months. Farm activities were the following:

- Land clearing. Farmers sprayed herbicide then plowed the soil. In some instances, if they had very limited time, some farmers did not plow the soil as long as they sprayed herbicide.

- $\quad$ Planting. After plowing, it was now time to plant the suckers. Months of September - December was their planting season. Twenty-five thousand $(25,000)$ suckers were planted per hectare. Some farmers mostly intercropped it with banana (See Appendix 2) or in minimal instances they intercropped pineapple with corn.

- $\quad$ Fertilizer application. They applied fertilizer to the main stem three times per cropping. If they planted in September, first application would be December- January (after three months from planting). Then second application was July the following year (after seven months from first application) and the last application was January (six months after second application).

- Weed management. Farmers visited their farms, removed and controlled the weeds by spraying herbicide.

- Cover hay - In April (22 months from planting) they covered the fruits with hay for protection from the sun (See Appendix 3) because weather in Isabela was very hot during this month.

- $\quad$ Harvest. - In May, they regularly visited the farms to check if the fruits were ready for harvest. The peak of their harvest was during the months of June till July. During harvest, they placed their produce in "kariton" (Appendix 4) to transport the fruits nearby the road then classified pineapples (Appendix 5) according to size like: "premera" which was P 25.00/pc (2.5kg -3kg), "segunda" which was P 20.00pc (1.5kg - 2.5kg), "tersera" which was P15.00/pc (1kg-1.5kg), and "buraot" which was 3 for P $100.00 / P 10.00$ (below $1 \mathrm{~kg})$. A truck of trader (Appendix 6) would be waiting during sorting then put the sorted fruits in the truck to be delivered to different destinations.

\section{Average Production Volume}

Table 4 shows the production volume of pineapple growers in Isabela particularly in the municipality of Echague, San Guillermo, and Sto. Tomas. Out of 84 farmers, $25 \%$ of them harvested more than 25,000 pcs of pineapple which means that their production area was more than one hectare. Though, $22.6 \%$ harvested below 5,000 pcs, $19 \%$ pineapple farmers produced $5,000-9,000$ pcs, $11.9 \%$ produced $10,000-14,999$ pcs, and $7.1 \%$ produced $15,000-19,999$ pcs. According to farmers, the average production per hectare was around $24,000-25,000$. This data would not be far from the $23,588.13$ mean as shown in table 2 .

\section{Table 4: Production Volume of Pineapple Growers in Isabela (in pcs.)}

\begin{tabular}{|l|c|c|}
\hline Production & f & \% \\
\hline below 5,000 & 19 & 22.6 \\
\hline 5,000 to 9,999 & 16 & 19.0 \\
\hline 10,000 to 14,999 & 10 & 11.9 \\
\hline 15,000 to 19,999 & 6 & 7.1 \\
\hline 20,000 to 24,999 & 8 & 9.5 \\
\hline 25,000 and above & 21 & 25.0 \\
\hline No response & 4 & 4.8 \\
\hline Total & 84 & 100 \\
\hline Mean & \multicolumn{2}{|c|}{$23,588.13$} \\
\hline Sd & \multicolumn{2}{|c|}{259.34} \\
\hline
\end{tabular}

\section{Marketing Channel}

The marketing channel of pineapple in Isabela is composed of four intermediaries namely: canvassers, traders, processors, and retailers. Canvassers are agents/assemblers who go to different farmers to buy/gather their produce and sell it to traders; traders are those who sell pineapples to processors or retailers; processors are those who process pineapple into vinegar, jam, and dried pineapple or in any product forms; retailers are the last intermediary in the marketing chain. 


\section{Figure 1: Marketing Channels of Pineapple in Isabela}

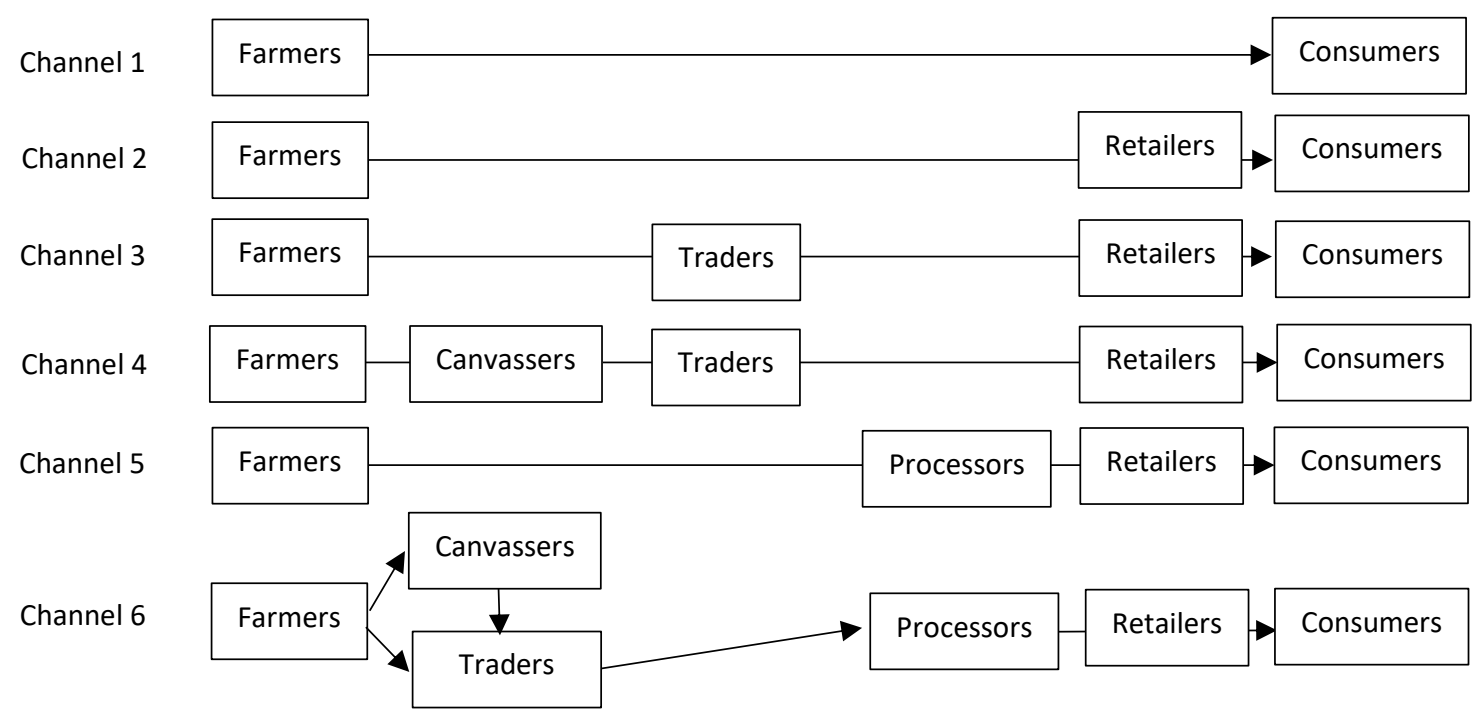

Figure 1 depicts the six marketing channels of pineapple in Isabela. Marketing channel 1 was the simplest in which no intermediary was involved. In distribution management, this is called zero (0) level. The farmers directly sell their produce to consumers. The second channel had one intermediary who are the retailers. Retailers are the last middlemen before the consumers. Further, the third marketing channel involved traders and retailers. In marketing channel 4 , canvassers entered in the scenario before traders and retailers. Marketing channel 5 had two intermediaries who were processors and retailers. The last channel would likely be complicated. From farmers, pineapples were bought by canvassers then sold them to traders then the next intermediary were the processors then passed on to retailers. Further, farmers would sell the fruits to traders then these traders would sell them to processors then passed to retailers until it would reach the consumers. Farmers sold their produce to canvassers, traders, and retailers as fresh fruit. Canvassers added P 1.00 mark-up per fruit when they sold their produce to traders. Other farmers were traders and/or retailers at the same time. Some of them transported their produce to different destinations, however, some traders picked-up the produce in the place of the farmers. Most buyers were their regular buyers or "suki". Buyers mode of purchase and payment was wholesale and cash basis respectively, though, very few farmers sold produce at retail price. In some instances, few farmers accepted credit or consignment basis.

Pineapples in Isabela were sold in Cagayan Valley particularly in the different municipalities in Isabela like: San Guillermo, Echague, Roxas, Santiago City, Cabagan, Sto. Tomas, Luna, and Alicia; Central Luzon (Nueva Ecija, Bulacan, Tarlac, Pampanga, Bataan and Zambales); llocos Region (Urdaneta Pangasinan); and National Capital Region (Balintawak, Quezon City and Taguig City). To those farmers who were traders and/or retailers at the same time, they transported and sold the fruit at Riverview Market and Juliana Market, Balintawak, Quezon City. There were also "pure" retailers in the said public market in which they sold pineapple all year round. All pineapple farmers sell fresh fruit. Very few processed the reject fruit as vinegar. Most reject pineapples were given to animals as their food or they just simply disposed them. Hi-Las Marketing is one of the processors of dried pineapples. The company gets their supply from Isabela as well as Cagayan. All dried pineapple manufactured by HiLas Marketing Corporation were transported to Japan and United Kingdom. Aside from Isabela, the company's other source of pineapple is in Mindanao.

\section{Marketing Practices}

The heart of the business is the consumers whose demand have to be fulfilled. In this study, consumers are referred to as buyers of pineapple. Buyers could be customers who purchase pineapple; consumers who eat pineapple; canvassers who purchase pineapple then sell them to another intermediary; processors purchase pineapple to further process it; and retailers purchase pineapple and sell them to consumers. Pineapple farmers are the sellers of pineapple. Hence, they need to satisfy the 
demand of their buyers. Buyers always look for a reasonable price with good quality product. As said earlier, farmers are the sellers, thus, they should know the prevailing price in the market to know how much to negotiate with the buyers.

Type of Buyers. Farmers sell their produce mostly to traders. They also sell pineapples to canvassers, retailers, consumers and processors. Very few farmers sell their produce directly to consumers because it would be more convenient for them to sell pineapples to traders and canvassers since the latter go directly to the place of the farmers.

Reason for choosing the type of buyers. Farmers already gained "suki" or loyal customers because they have been in the pineapple industry for quite a long time. Some have no choice but to sell the fruit to any buyers because they want immediate cash since they waited 24 months after harvest time. High price is also one factor why farmers would choose to sell their produce. Consumers always look for convenience, but in this case, farmers also need accessibility or convenience to sell the goods because some of them are not expert in marketing their produce.

Basis in determining the quality of their produce. The number one factor in determining the quality of the pineapple is the size. There are different sizes of pineapples which are sold in the market: "premera", $2.5 \mathrm{~kg}-3 \mathrm{~kg}$, "segunda", $1.5 \mathrm{~kg}-2.5 \mathrm{~kg}$, "tersera", $1 \mathrm{~kg}-1.5 \mathrm{~kg}$, and "buraot" would be below $1 \mathrm{~kg}$. Most consumers prefer sweet taste when eating fruits, it is evidenced in this study that taste was also a factor in determining the quality of the pineapple. Some would prefer color since it reflects how sweet or how fresh the pineapple would be. Appearance and shape showed minimal effect in determining the quality of the fruit.

Reasons for product rejection. Based on the previous discussion, appearance and shape were the least factor in determining the quality of the fruit. Nevertheless, appearance was the reason why their fruits were rejected. Again, in the previous discussion, size showed significant effect in determining the quality of the fruit; it is evident in this study that size would matter why pineapples were rejected. Moreover, color was also a factor of product rejection. This data showed consistency on the basis of product quality and product rejection.

Price monitoring. Majority of farmers monitor the current selling price of pineapple. Every product has a corresponding price. Thus, price matters to farmers. Price was the reason why they planted pineapple for them to gain income. Co-farmers and traders were the source of price information. Farmers always inquire from their co-farmers for the prevailing selling price; how much did the trader or canvasser buy their pineapple? Sometimes traders dictate the price based on the supply and demand. Thus, if there were many pineapples, the trader would set low price.

Price negotiation. In business, negotiation is every significant. Negotiation is a discussion between the buyer (canvasser/trader) and the seller (farmer) to reach a mutual agreement. Farmers negotiate with their buyers to arrive at a reasonable buying price. Very few farmers just wanted to sell their produce because 24 months (planting to harvesting) would be a long wait for them to gain an income. As a golden rule in selling, if one buys in bulk he gets more discounts. During price negotiation, volume would be the number one factor. Next was "win-win" situation where both buyers (canvassers/traders) and the sellers (farmers) would benefit. Some farmers have contracts / tie-ups where they have already developed a good business relationship with their "suki" or loyal buyers.

\section{CONCLUSION}

Isabela is the second largest pineapple producer in Cagayan Valley. Based on the record of the Office of the Provincial Agriculturist in Isabela an estimated of 425.66 hectares were planted by pineapple. About 287.75 hectares are found in Echague, 86.87 hectares are found in San Guillermo, 27.89 hectares is found in Sto. Tomas, 18.65 hectares are in Jones, and 4.50 hectares are in Angadanan. Activities of pineapple farming are land clearing, planting, fertilizer application, weed management, cover hay, and harvest. In land clearing, farmers clean the area, plow the soil, and spray herbicide. An estimated of 25,000 suckers were planted per hectare. To maximize the land, they also intercropped it with banana. To produce better quality fruit, they applied fertilizer regularly. Every now and then they removed the weeds by spraying herbicides. Isabela's climate is humid, hence, to protect the fruit from the sun, they cover the pineapple with hay. After twenty-four months from planting, it would be time for them to harvest. The average production volume of pineapple growers in Isabela was about 23,588 pieces. In the field of pineapple industry, the manufacturers or producers are the farmers. Middlemen or intermediaries are very significant in the marketing channel because they bring the products to the consumers. Canvassers, traders, processors, and retailers are the intermediaries in the pineapple industry. Majority of farmers sold their produce to traders or their usual buyers or "suki." Size was the number one factor in determining the quality of pineapples, thus, this is the reason why their products were rejected aside from appearance. Furthermore, good product handling was their method of observing product quality. In terms of price, they gathered information from their co-farmers and traders. Determining the price was based on the bulk of order and winwin situation in which both parties would benefit. Most farmers did not have the capacity of marketing their produce. They just 
waited for their buyers to come in their area. Marketing was not their number one concern, however, marketing channel is still important in every product. Intermediaries are still involved along the chain. In $2016,97.7 \%$ of all Filipino pineapple exports were sold to other countries (Santiago, 2017). International market serves as window for Filipino pineapple farmers. Pineapples in Isabela are sweet and tasty. It could compete in international business, however, they could not supply the huge demand in the market. It would be of great advantage to increase the production area to increase the harvest.

\section{REFERENCES}

Apandi, F.H. et al (2017). Factors Influencing the Choice of Pineapple Marketing Channel in Samarahan, Sarawak. Journal of Fundamentals and Applied Science, 9 (7S), 571-583.

Das, B. et al (2016). Study on Marketing System and Value Addition of Pineapple Fruit (Ananus comosus) in West Bengal. Agricultural Economics Research Review, 29 (2), 279-285.

Yusi, M.S. (2016). The Analysis of Production Function and Farm Marketing efficiency of pineapple (Ananas comosus L Merr) in South Sumatera Province, Indonesia. African Journal of Agricultural Research, 11 (23), 1990-1998.

Agarwal, R. (n.d). Distribution Channel: Functions and Levels (With Diagram). Retrieved from

http://www.yourarticlelibrary.com/retailing/distribution-channel-functions-and-levels-with-diagram/48299

Arcelo, M. (nd). Production Guide for Pineapple. Retrieved from

http://bpi.da.gov.ph/bpi/images/Production_guide/pdf/Pineapple\%20.pdf

Blunt, L. (2019). Types of Marketing Channels. Retrieved March 25, 2019 from https://smallbusiness.chron.com/typesmarketing-channels-21627.html

Joy, P.P (2010). Benefits and Uses of Pineapple. Retrieved from

https://www.researchgate.net/publication/306017037_Benefits_and_uses_of_pineapple

Khan, H. (2018). Top 10 Largest Pineapple Producing Countries in the World. Retrieved from

https://www.worldblaze.in/pineapple-producing-countries/

Rodeo, AJ D. (2016). The Philippine Fruit Industry: An Overview. Retrieved from

https://www.researchgate.net/publication/311067359_The_Philippine_Fruit_Industry_An_Overview

Philippine Statistics Authority. www.psa.gov.ph

Santiago, D. (2017). Philippines Pineapples Exports by Country. Retrieved from:

http://www.philippinesaroundtheworld.com/philippines-pineapples-exports-by-country/

Szalay, J. (2018). Pineapple: Health Benefits, Risks \& Nutrition Facts. Retrieved from https://www.livescience.com/45487-

pineapple-nutrition.html 
Appendix 1: Key Pineapple Production Areas in Isabela

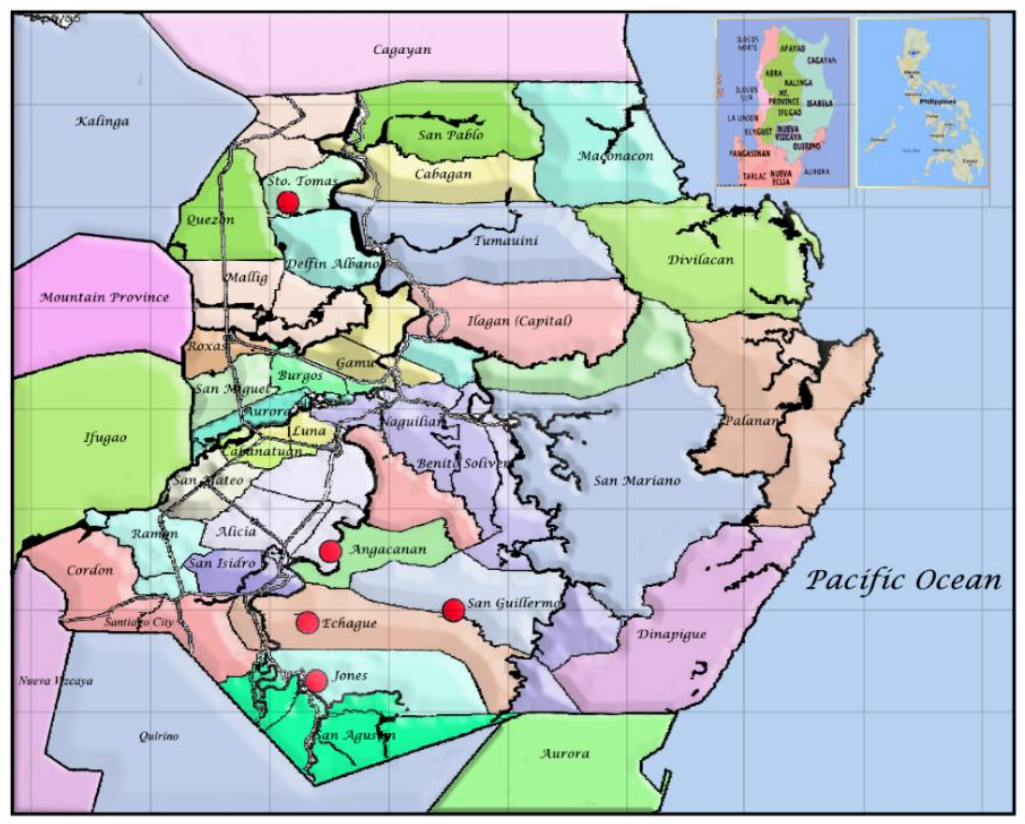

Appendix 2: Pineapple Intercrop with Banana

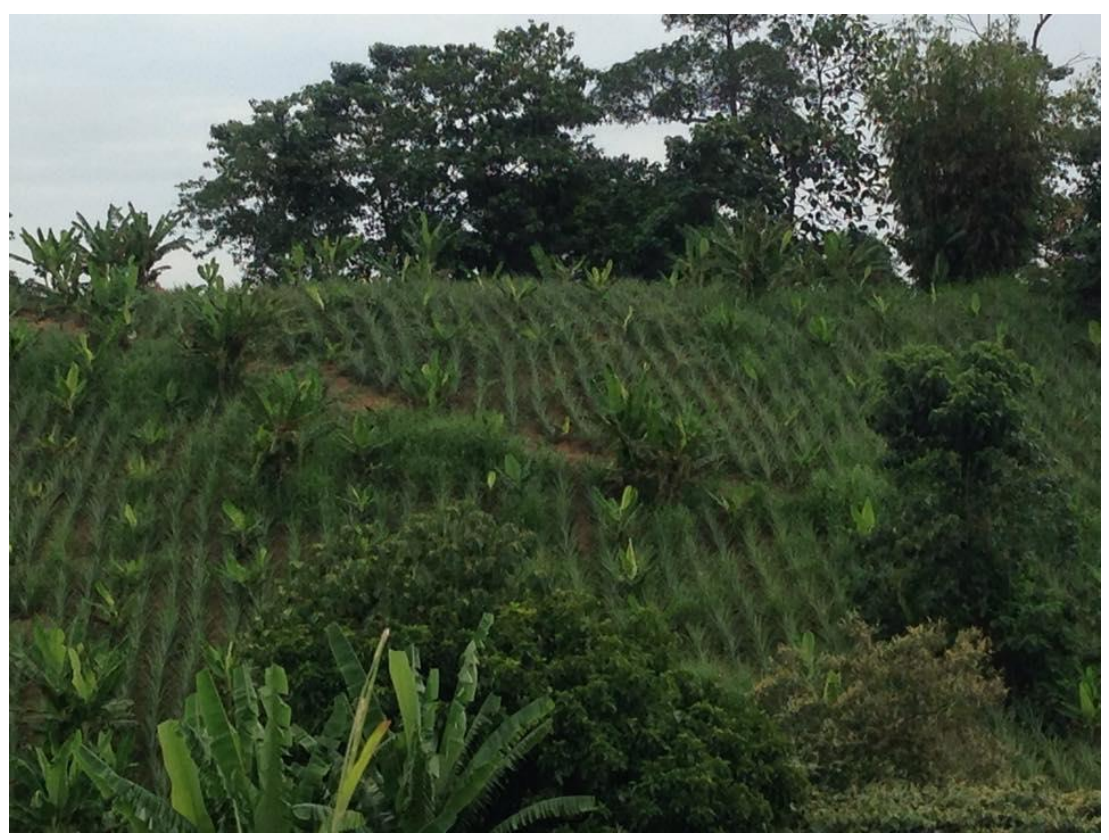




\section{Appendix 3: Pineapple covered with Hay}

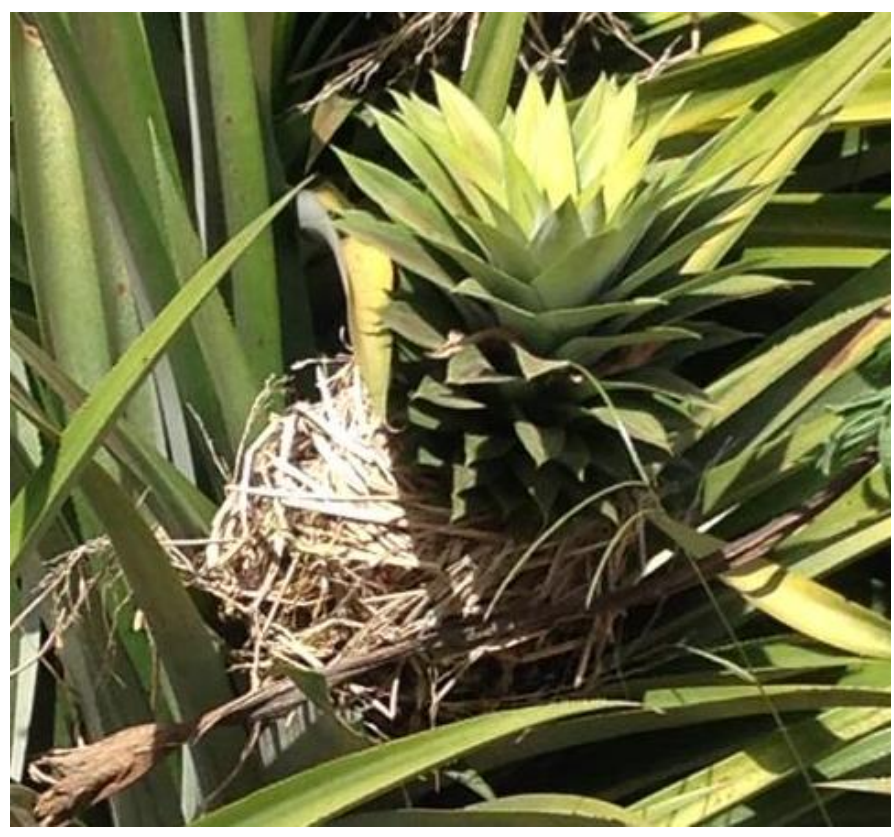

\section{Appendix 4: Kariton}

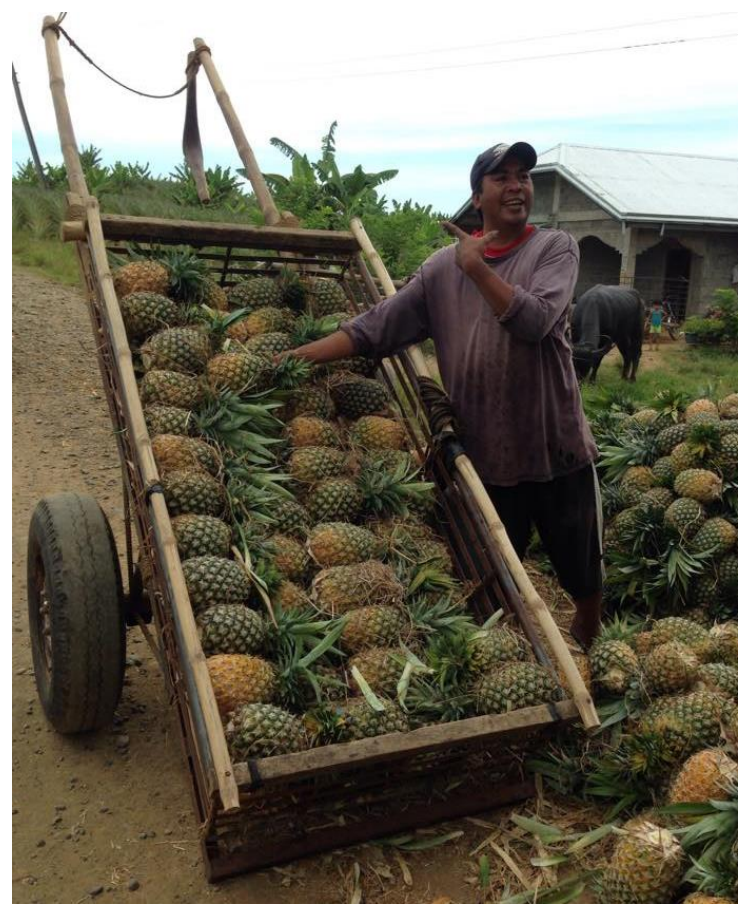




\section{Appendix 5: Sorting}

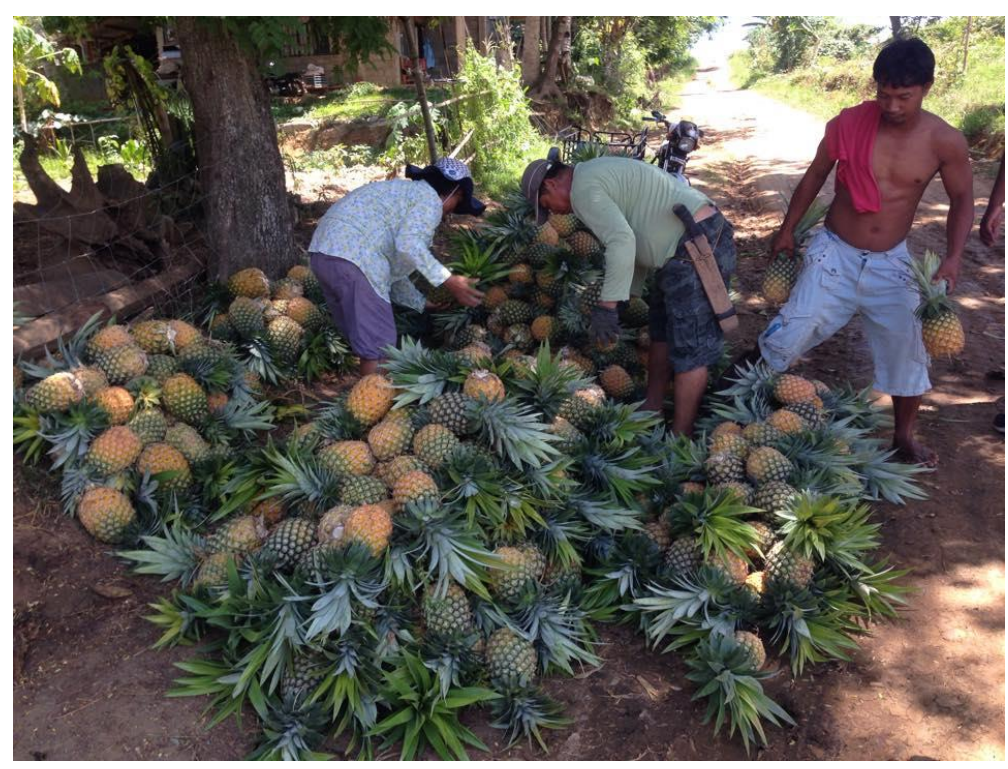

Appendix 6: Ready to Transport

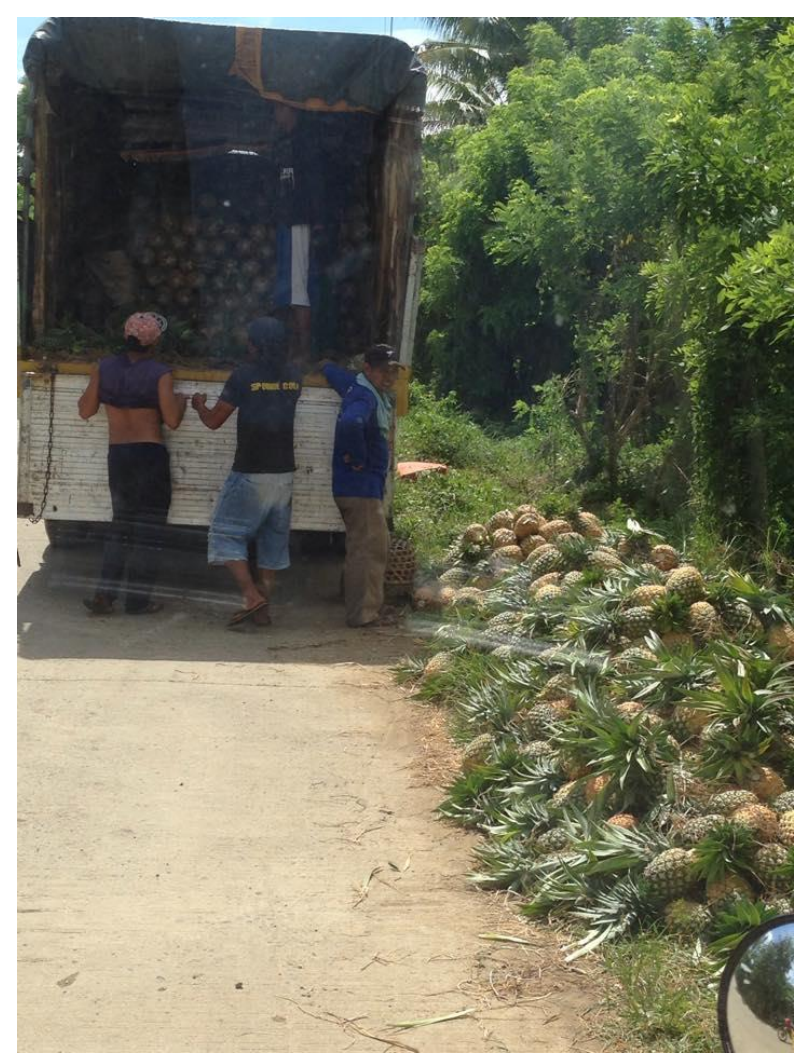

